\title{
Mathematical Analysis of Criteria for Maintenance of Technical Systems in the Function of Achieving Sustainability
}

\author{
Goran Otić $^{1}$, Oliver Momčilović ${ }^{2}$, Ljiljana Radovanović ${ }^{3, * \mathbb{D}}$, Goran Jovanov ${ }^{4} \mathbb{D}$, Dragica Radosav ${ }^{5}$ \\ and Jasmina Pekez ${ }^{3}$ (D)
}

check for updates

Citation: Otić, G.; Momčilović, O.; Radovanović, L.; Jovanov, G.;

Radosav, D.; Pekez, J. Mathematical Analysis of Criteria for Maintenance of Technical Systems in the Function of Achieving Sustainability.

Sustainability 2021, 13, 1680.

https://doi.org/10.3390/su13041680

Academic Editor: António Abreu

Received: 31 December 2020

Accepted: 30 January 2021

Published: 4 February 2021

Publisher's Note: MDPI stays neutral with regard to jurisdictional claims in published maps and institutional affiliations.

Copyright: (c) 2021 by the authors. Licensee MDPI, Basel, Switzerland. This article is an open access article distributed under the terms and conditions of the Creative Commons Attribution (CC BY) license (https:// creativecommons.org/licenses/by/ $4.0 /)$.
1 Military Medical Academy, Crnotravska 17, 11000 Belgrade, Serbia; goran.otic@gmail.com

2 Department of Engineering Management, Faculty of Information Technology and Engineering, University “Union-Nikola Tesla”, Belgrade, Jurija Gagarina 149a, 11070 New Belgrade, Serbia; oliver.momcilovic@fiti.edu.rs

3 Department of Mechanical Engineering, Technical Faculty "Mihajlo Pupin", University of Novi Sad, Đure Đakovića bb, 23000 Zrenjanin, Serbia; jasmina.pekez@tfzr.rs

4 Department of Forensics, University of Criminal Investigation and Police Studies, Cara Dušana 196, 11080 Belgrade, Serbia; goran.jovanov@kpu.edu.rs

5 Department of Information Technology, Technical Faculty "Mihajlo Pupin”, University of Novi Sad, Đure Đakovića bb, 23000 Zrenjanin, Serbia; dragica.radosav@tfzr.rs

* Correspondence: ljiljana.radovanovic@tfzr.rs

\begin{abstract}
Achieving sustainable development requires strategic efforts involving the entire organization. Maintenance efforts also play an important role. Company management needs to understand and develop an appropriate strategy to achieve sustainable development by applying maintenance performance measurements. The aim of this paper is to present possible ways of analyzing and ranking the impact of certain criteria with respect to achieving sustainability. The paper uses the method of Structural Equation Modeling-SEM in order to determine the most influential variable on the sustainability of maintenance of technical systems. Based on the set theoretical system model, for all its variables in the model, statements were made that describe them, on which 136 respondents gave their views (from 1 to 5, Likert scale) in the territory of the Republic of Serbia. An intuitive F-DEMATEL method was also used to prioritize variables. A team of 10 experts in the field of maintenance of technical systems was compared the criteria A-Application of technical diagnostics, $\mathrm{B}$-Management of maintenance resources, $\mathrm{C}$-Maintenance process planning, and the dependent variable D-Sustainability of maintenance of technical systems. According to experts, the importance of the criteria coincides with the results obtained by a survey with 136 respondents.
\end{abstract}

Keywords: criteria; maintenance; sustainability; SEM; F-DEMATEL

\section{Introduction}

Maintenance is the basic logistics of industrial systems, both in terms of their working capacity and in terms of meeting the requirements of environmental protection and sustainable development of the maintenance as a whole. It is a multidisciplinary set of indirect (preparatory) and direct (executive) activities to predict, prevent and eliminate failures of machinery and equipment in order to achieve the optimal degree of system effectiveness [1].

Sustainable Maintenance (SM) should contribute to the minimization of environmental and social impacts of a system, the reduction of life cycle costs and enhancement of equipment durability and socioeconomic well-being [2].

Some papers suggest a preliminary framework to integrate sustainability issues into the maintenance performance measurement in automotive companies $[3,4]$ and in maintenance dashboards [5] or rank attributes/indicators that contribute to a Sustainable Maintenance performance evaluation [6-8]. In research [9], the sustainability improvements achieved, relative to the company's initial situation after implementing a lean and green 
manufacturing system, instead propose the new OEEE (Overall Environmental Equipment Effectiveness) indicator to evaluate the environmental impact of the asset life cycle. A common general classification of sustainable performance indicators for maintenance is not found using the Scoping Literature Review. It will be necessary the integration of such indicators in maintenance policies to achieve a Sustainable Maintenance management [10].

This paper assesses the relative importance of each of the best criteria for the sustainable management of the maintenance of national heritage buildings in Malaysia. The results show that "training and expertise of maintenance staff" are the most important criteria that respondents consider to be key in supporting sustainable best practice [11]. Sustainable maintenance has introduced a new category into the two previously existing ones (economic and environmental). The third category is social issues and the search for a balance between three aspects: financial, environmental, and social. Consequently, natural maintenance is included in the realization of a sustainable production approach. From practical point of view, it requires changes in approach to maintenance represented by managers and changes in actions performed within maintenance area [12].

Mathematically, if sustainable maintenance practice is denoted by an acronym (SMP), then the connecting equation expressing the $\mathrm{SMP}$ is given in $\mathrm{SMP}=\mathrm{F}(\mathrm{M}, \mathrm{D}, \mathrm{P}, \mathrm{C}, \mathrm{F}, \mathrm{M}, \mathrm{E})$ where $\mathrm{M}$ is the machine records keeping, $\mathrm{D}$ is diagnostic technique, $\mathrm{P}$ stands for prognostic technique, and $\mathrm{C}$ is the machine condition monitoring technology. These four factors are inherent and internal factors associated with data keeping. F, M, and E stand for machines functionality, manufacturability, and environmental impact, respectively. These three factors are external factors imposed on the machines due to demand pressure and rivalry competitions that may arise in the course of production, which will in one way or another affect the machinery functionalities [13].

The main goal of research [14] is to define a sustainable approach for the maintenance of asphalt pavement construction. Predictive maintenance is inevitable for sustainable smart manufacturing in I4.0 in research [15].

\section{Objectives of the Maintenance Process}

Maintenance is a process that enables the management of technical condition and reliability throughout the entire life cycle of the system. Furthermore, maintenance goals, among other things, go into the sphere of business economics, so they are expressed in the form of rationalization and are in principle measurable. The main goals to be achieved in the maintenance process which are also in the function of sustainability are [16] the following:

- Providing (maximizing) the required level of reliability of technical systems in the process of exploitation (reliability is the probability of operation without failure during time period, with the greatest possible availability of the system and with as few failures as possible);

- Minimization of total maintenance costs (direct and indirect);

- Prevention and limitation of obsolescence of technical systems;

- Joint participation (with all functions in the company) in production and financial management (integration into the CIM production system, i.e., computer-integrated production);

- Achieving better product quality;

- Increasing labor productivity in production;

- Increasing the level of motivation for work (faulty technical systems cause bad conditions and relationships, and even accidents, both in the company and its environment);

- Keeping all available resources in the company;

- Knowledge management;

- Delivery of products to customers on time, etc. 


\section{Formulating a New Vision of Maintenance}

The main purpose of the maintenance system is to ensure the efficient operation of the company with the shortest possible downtime. Creating a vision of one of the strategically capable maintenance systems is the basic driving force of the company. The goal of such a conceptualized maintenance is to incorporate this fact into all company processes. This means that maintenance employees, regardless of their expertise, must understand that their primary role is to contribute to the company profitability.

The basic functions of the organizational maintenance system are [17] the following:

- Diagnosing the causes of technical system failure;

- Elimination of the resulting failure condition.

However, basic functions cannot exist on their own. Continuous functional maintenance means that the system must contain the following set of functions:

- A set of functions to ensure continuity;

- A set of operational service functions;

- A set of operational management functions.

The basic aspect of achieving the functioning and survival of the organizational maintenance system is to provide a financial function. A financial function is needed to provide the necessary resources in the form of equipment, technical and other materials. However, in addition to the necessary financial resources, a functional maintenance process must also include materials, equipment, and technical apparatus in order to be able to perform basic functions. All these items belong to the function of providing material and technical resources.

The fourth necessary function to achieve continuity of maintenance is the required human resource. Well-trained and professional staff should be behind the quality functioning of maintenance. Professional, technical staff of various profiles with accompanying administrative staff make the maintenance system as it is. Hiring staff, predicting the required number of employees, middle technical staff to perform the function F0 with the accompanying administrative staff for the implementation of smooth maintenance work is a function of providing human resources. The financing of salaries of employees is within the scope of the financial function and is paid on the basis of the required gross funds for the payment of salaries at the company level.

The following set of functions that plays an important role in achieving maintenance continuity is a set of operational service functions [17]:

- Information provision function;

- Function for monitoring economic and financial trends;

- Function of ensuring the correctness of technical support;

- Legal problem solving function;

- Function of ensuring the correctness of functioning.

\section{Identifying Maintenance Criteria for Achieving Sustainability}

Based on the review of domestic literature [16,18-24], foreign literature [25-28], research in our country [29-32], the following aspects or elements of maintenance for which is important to establish an adequate management system are listed [17]:

- Maintenance staff;

- Maintenance organization;

- Maintenance planning;

- Quality control in maintenance;

- Application of information technologies in the maintenance process;

- Spare parts, equipment, and maintenance materials;

- Existing technical systems, protection, supervision, and diagnostic equipment;

- Technical diagnostics;

- Development of maintenance technology;

- Application of modern maintenance methodologies; 
- Decision making in the maintenance process;

- Maintenance costs.

The impact of each of the mentioned maintenance criteria on sustainability will not be considered in this paper. Namely, this is only a proposal of certain criteria that are used as a framework for defining influential or relevant criteria for sustainability for a particular company in a particular industry.

\section{Materials and Methods}

\subsection{Theoretical Settings, Structural Equation Modeling-SEM}

During the 1970s, a lot of work was done on the development of mathematicalstatistical causal analysis that would enable testing and proving causal hypotheses in the field of social sciences. For these purposes, Structural Equation Modeling (hereinafter SEM) is often present [33-35]. In current research in various fields of psychology, SEM is an integral part of research methodology [36-38]. Modeling with structural equations presents a series of hypotheses about how the variables in the analysis are generated and how they relate to each other $[39,40]$. SEM includes analysis of latent variables and pathway analysis to test hypothetical models and detect the relationship of manifest and latent variables [34]. Modeling by structural equations in this paper is used to study the correlation and regression analyzes of variables of the system model set. Correlation analysis is used to researches and quantifies the connection between the observed phenomena, i.e., variables. The correlation coefficient shows the degree of statistical correlation of phenomena, i.e., variables. In this research, the coefficient of multiple linear correlation is used, which means that the degree of existence of a linear relationship of one in relation to two or more variables is studied. This degree is calculated by (Formula (1)):

$$
r=\frac{\sigma_{x y}}{\sigma_{x} \cdot \sigma_{y}}
$$

wherein

$\sigma_{x}$ and $\sigma_{y}$-standard deviations of variables $\mathrm{X}$ and $\mathrm{Y}$;

$\sigma_{x y}$-covariance (arithmetic mean of the product of the deviation of variables from their arithmetic means).

Regression analysis determines the analytical relationship between the phenomenon, i.e., the variables. If the model expresses a linear relationship between dependent variables and two or more variables, it is a multiple linear regression model. The simplest form of dependence is given (Formula (2)):

$$
y=a x_{1}+a x_{2}+a x_{3}+\cdots a x_{k}+b
$$

wherein

$a$-regression coefficient—which shows how much the dependent variable changes on average, if the independent variable changes by one;

$b$-is a constant and shows the value of the dependent variable in the case when the independent variable equals zero.

\subsection{Theoretical Assumptions of the F-DEMATEL Method}

Proposed intuitive F-DEMATEL method for determining the priority of variables (hereinafter criteria) in a typical decision-making problem, which consists of 10 steps by [41-43]:

Step 1. In order to achieve the goals of decision-making, it is necessary to establish a team of experts. This team must include experts with good experience and knowledge in the appropriate field of decision making.

Step 2. Assessing alternatives would be insignificant without considering a set of criteria. An effective set of criteria will provide a better assessment. Therefore, it is 
necessary to identify criteria for evaluating the problem, using a fuzzy matrix of direct assessments. Experts should determine the relationships between the criteria by giving their views, based on the Intuitistic Fuzzy Linguistic Scale of five comparisons (Table 1), as follows: 0 (no impact), 1 (small impact), 2 (medium impact), 3 (high impact), and 4 (very high impact) (Table 1). Based on this scale, experts give their linguistic assessments for the interrelationships between the defined criteria. Trapezoidal fuzzy numbers are used for evaluation.

Table 1. Intuistic Fuzzy linguistic scale.

\begin{tabular}{cccc}
\hline Linguistic Phrase & $\begin{array}{c}\text { The Result of } \\
\text { the Impact }\end{array}$ & $\begin{array}{c}\text { Intuitive Trapezoidal } \\
\text { Fuzzy Number }\end{array}$ & Expected Crips Value \\
\hline no influence (NI) & 0 & $(0 ; 0 ; 0 ; 0)$ & 0 \\
low influence (LI) & 1 & $(0 ; 0.1 ; 0.2 ; 0.3)$ & 0.15 \\
medium influence (MI) & 2 & $(0.3 ; 0.4 ; 0.5 ; 0.6)$ & 0.45 \\
high influence (HI) & 3 & $(0.7 ; 0.8 ; 0.9 ; 1)$ & 0.85 \\
very high influence (VHI) & 4 & $(1 ; 1 ; 1 ; 1)$ & 1 \\
\hline
\end{tabular}

Step 3. Since trapezoidal fuzzy numbers are not suitable for matrix operations, it is necessary to convert or dephase trapezoidal fuzzy numbers into crips numbers. The fuzzy intuitionistic direct relative matrix $(\mathrm{M})$ is given (in Formula (3)).

$$
M=\frac{1}{4}\left(a_{1}+a_{2}+a_{3}+a_{4}\right)
$$

Step 4: Normalized matrix of the direct relation $(\mathrm{N})$ derived by using the (Formulas (4) and (5)) [44]:

$$
\begin{gathered}
L=\operatorname{Min}\left[\frac{1}{\operatorname{Max} \sum_{j=1}^{n} a_{i j}}, \frac{1}{\operatorname{Max} \sum_{i=1}^{n} a_{i j}}\right] \\
N=L \times M
\end{gathered}
$$

Step 5. Construction of a matrix of total relations. Standardized direct relative matrix $(\mathrm{N})$ is transformed into the matrix of total relations (T) based on (Formula (6)):

$$
T=N \times(I-N)^{-1}
$$

Step 6. Obtaining causal parameters is done using the following formulas, where D stands for the sum of columns, and R the sum of rows (Formulas (7) and (8)):

$$
\begin{aligned}
& D=\left[\sum_{j=1}^{n} a_{i j}\right]_{1 \times n} \\
& R=\left[\sum_{i=1}^{n} a_{i j}\right]_{n \times 1}
\end{aligned}
$$

Step 7-Obtaining the importance of the criterion "can be calculated by taking into account the values of $(\mathrm{D}+\mathrm{R})$ and $(\mathrm{DR})$ " by $[45,46]$, and is given (in Formula (9)):

$$
\omega_{i}=\left\{(D+R)^{2}+(D-R)^{2}\right\}^{\frac{1}{2}}
$$

Step 8-The importance of any criterion can be obtained by normalization shown (in Formula (10)):

$$
W_{i}=\frac{\omega_{i}}{\sum_{i=1}^{n} \omega_{i}}
$$

where $i=1,2, \ldots, n$. 
Step 9. The adjustment of the threshold value $(\alpha)$ is calculated from the matrix of the total relations (T) using Formula (11) and aims to eliminate some criteria in the matrix:

where $\mathrm{N}$ is the arithmetic mean of the quantities from the matrix of total relations ( $\mathrm{T}$ )

$$
\alpha=\frac{\sum_{i=1}^{n} \sum_{j=1}^{n}\left[a_{i j}\right]}{N}
$$

Step 10. Drawing a diagram of causality and effect consists of $(D+R)$ and $(D-R))$ values.

\section{Results}

In addition to providing material resources for maintenance, the company also has the problem of providing the necessary expertise and knowledge of employees involved in maintenance. Technological advance and consequently the need to upgrade equipment require different company management strategies. Demands that existing equipment be used and exploited for as long as possible and the desire to own the best available equipment are opposed. It is no secret that manufacturers of equipment and machinery generate a large part of their income through the sale of spare parts and maintenance services. Especially, it is not easy to replace expensive and valuable equipment. Products and machines are not standardized, i.e., there is a large number of manufacturers of different products. This diversity complicates the problem of equipment and machine maintenance. A particularly important problem is the age of the equipment where the parent manufacturers stopped producing spare parts. From all of the above, many users of equipment and machines decide to rent equipment where the rental price is also the price of proper operation. The company then focuses on its core process, leaving maintenance to a kind of outsourcing. Thanks to significantly advanced IT technologies and means of transport, special services and maintenance services can react quickly in case of need.

In accordance with the aforementioned, authors decided to single out the three criteria that will be analyzed from the aspect of impact on sustainability, and they are the following:

- Application of technical diagnostics;

- Maintenance resource management;

- Maintenance process planning.

Figure 1 shows the theoretical system model, and it consists of the following independent variables: A-Application of technical diagnostics (hereinafter variable A), B-Management of maintenance resources (hereinafter variable B), C-Maintenance process planning (hereinafter variable C), and the dependent variable D-Sustainability of maintenance of technical systems (hereinafter variable D).

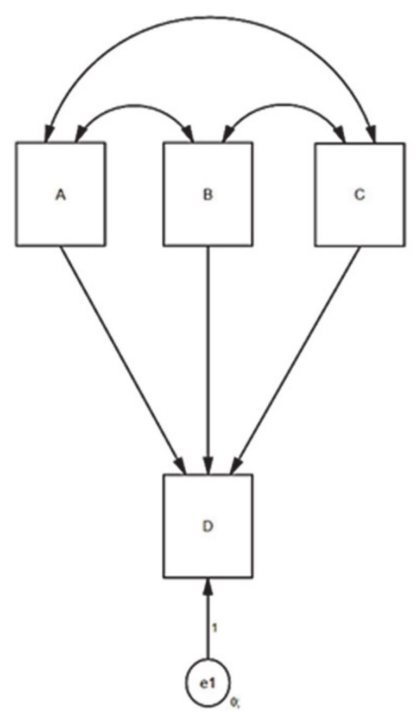

Figure 1. System research model. 
Based on the set theoretical system model, for all its variables in the model, statements were made that describe them and on which 136 respondents gave their views (from 1 to 5 , Likert scale) in the period from 1 August 2020 to 1 November 2020, on the territory of the Republic of Serbia, as follows:

- Variable A-Application of technical diagnostics consists of the following statements:

- $\quad \mathrm{A}_{1}$-Validation affects the maintenance of technical systems;

- $\quad \mathrm{A}_{2}$-Functional checking affects the maintenance of technical systems;

$\circ \quad \mathrm{A}_{3}$-Security checking affects the maintenance of technical systems;

$\circ \quad \mathrm{A}_{4}$-Monitoring of technical systems affects the maintenance of technical systems.

- Variable B-Management of maintenance resources consists of the following statements:

- $\quad B_{1}$-Human resource productivity has an impact on the maintenance of technical systems;

- $\quad \mathrm{B}_{2}$-Management of spare parts for maintenance systems of technical systems;

$\circ \quad B_{3}$-Proper functioning of equipment has an impact on the maintenance of technical systems;

- $\quad \mathrm{B}_{4}$-Assessment of the service life of equipment used to maintain technical systems;

$\circ \quad \mathrm{B}_{5}$ - Operating conditions with equipment load used to maintain technical systems;

$\circ \quad \mathrm{B}_{6}$-Equipment renting (outsourcing) is used to maintain technical systems;

$\circ \quad \mathrm{B}_{7}$-The application of new technologies is used to maintain technical systems;

$\circ \quad \mathrm{B}_{8}$ - Supply system is used for maintenance of technical systems.

- Variable C-Maintenance process planning consists of the following statements:

- $\quad \mathrm{C}_{1}$-Maintenance cost planning affects the maintenance of technical systems;

$\circ \quad C_{2}$-Resource planning (materials, equipment, spare parts, labor) affects the maintenance of technical systems;

- $\quad \mathrm{C}_{3}$-Synchronization of maintenance plans and the production plan affects the maintenance of technical systems.

- Variable D-Sustainability of maintenance of technical systems consists of the following statements:

$\circ \quad \mathrm{D}_{1}$-Proper maintenance of technical systems contributes the greater environmental safety;

- $\quad \mathrm{D}_{2}$-Permanent monitoring of maintenance performance has an impact on the sustainability of maintenance of technical systems;

- $\mathrm{D}_{3}$ - Reliability of technical systems has an impact on the sustainability of maintenance.

The main null hypothesis of the research is $\mathrm{H}_{0}$ : Levels $\mathrm{A}-$ Application of technical diagnostics, B-Maintenance resources management, and C-Maintenance process planning significantly affect level D-Sustainability of maintenance of technical systems.

The values of descriptive statistics according to the work experience of the respondents are given in Table 2. The highest number of respondents was with 21-30 years of work experience, 60 or $41.11 \%$, and the lowest number of respondents was with less than 10 years of work experience, 12 or $8.82 \%$, out of the total number of 136 respondents.

Table 2. Descriptive statistics according to work experience of the respondents.

\begin{tabular}{ccccccc}
\hline Work Experience of the Respondents & $\mathbf{< 1 0}$ & $\mathbf{1 1 - 2 0}$ & $\mathbf{2 1 - 3 0}$ & $\mathbf{> 3 0}$ & All \\
\hline Frequency & 12 & 28 & 60 & 36 & 136 \\
Percentage & 8.82 & 20.58 & 41.11 & 26.47 & 100.0 \\
\hline
\end{tabular}

The values of descriptive statistics according to the educational background of the respondents are given in Table 3. More respondents had a high school diploma, 120 or $88.23 \%$, and fewer had a college or university degree, 16 or $11.76 \%$, out of the total number of 136 respondents. 
Table 3. Descriptive statistics according to work experience and educational background of the respondents.

\begin{tabular}{cccc}
\hline Educational Background & High School & College or Faculty & All \\
\hline Frequency & 120 & 16 & 136 \\
Percentage & 88.23 & 11.76 & 100.00 \\
\hline
\end{tabular}

Cross-sections according to work experience and educational background of the respondents are given in Table 4 as follows: most of them, 52 or $38.23 \%$, are the respondents with the work experience of 21-30 years and with a high school degree, and the least number of respondents, 2 or $16.67 \%$, out of 136 respondents, have work experience of less than 10 years and a college or faculty degree. We can say that the most respondents, 52 of them, or $86.67 \%$, out of a total of 60 respondents, are in the group with work experience of $21-30$ years, or $43.33 \%$, out of a total of 120 respondents with a high school degree. We can say that at least 2 respondents, or $1.47 \%$, out of 136 respondents, have less than 10 years of work experience or a college or faculty degree. Also, we can say that 2 respondents, or $16.67 \%$, out of 12 respondents, have work experience less than 10 years or a college or faculty degree, or $12.5 \%$, out of 16 respondents have a college or faculty degree.

Table 4. Crossed descriptive quantities according to educational background of the respondents.

\begin{tabular}{|c|c|c|c|c|c|c|c|c|c|c|c|c|c|c|c|}
\hline \multirow{2}{*}{$\begin{array}{l}\text { Work Experience of the } \\
\text { Respondents/Educational } \\
\text { Background of the Respondents }\end{array}$} & \multicolumn{3}{|c|}{$<10$} & \multicolumn{3}{|c|}{$11-20$} & \multicolumn{3}{|c|}{$21-30$} & \multicolumn{3}{|c|}{$>30$} & \multicolumn{3}{|c|}{ All } \\
\hline & $\mathbf{N}$ & $\begin{array}{c}\text { Column } \\
\%\end{array}$ & $\begin{array}{c}\text { Row } \\
\%\end{array}$ & $\mathbf{N}$ & $\underset{\%}{\text { Column }}$ & Row $\%$ & $\mathrm{~N}$ & $\underset{\%}{\text { Column }}$ & Row $\%$ & $\mathbf{N}$ & $\underset{\%}{\text { Column }}$ & Row $\%$ & $\mathbf{N}$ & $\begin{array}{c}\text { Column } \\
\%\end{array}$ & $\begin{array}{c}\text { Row } \\
\%\end{array}$ \\
\hline High School & 10 & 83.33 & 8.33 & 25 & 89.29 & 20.83 & 52 & 86.67 & 43.33 & 33 & 91.67 & 27.5 & 120 & 88.24 & 100 \\
\hline College or faculty & 2 & 16.67 & 12.5 & 3 & 10.71 & 18.75 & 8 & 13.33 & 50 & 3 & 8.33 & 18.75 & 16 & 11.76 & 100 \\
\hline All & 12 & 100 & 8.82 & 28 & 100 & 20.59 & 60 & 100 & 44.12 & 36 & 100 & 26.47 & 136 & 100 & 100 \\
\hline
\end{tabular}

The values of descriptive statistics for the group of statements for variable $\mathrm{A}$ are given in Table 5. Statement $A_{2}$ - has the highest mean score of 3.9852941, and statement $A_{1}$ - the lowest mean score of 3.7058824. The mean score of variable A is 3.8694853 .

Table 5. Descriptive statistics for all variables related to A.

\begin{tabular}{cccccc}
\hline $\mathbf{A}$ & $\mathbf{A}_{\mathbf{1}}$ & $\mathbf{A}_{\mathbf{2}}$ & $\mathbf{A}_{\mathbf{3}}$ & $\mathbf{A}_{\mathbf{4}}$ & All Variable A \\
\hline Mean & 3.7058824 & 3.9852941 & 3.9117647 & 3.8750000 & 3.8694853 \\
Std Dev & 1.0264476 & 0.9426935 & 1.0918594 & 1.1510864 & 0.9874054 \\
Std Err Mean & 0.0880172 & 0.0808353 & 0.0936262 & 0.0987048 & 0.0846693 \\
Upper 95\% Mean & 3.8799532 & 4.1451615 & 4.0969285 & 4.0702078 & 4.0369351 \\
Lower 95\% Mean & 3.5318115 & 3.8254268 & 3.7266010 & 3.6797922 & 3.7020354 \\
$\mathrm{~N}$ & 136 & 136 & 136 & 136 & 136 \\
\hline
\end{tabular}

The values of descriptive statistics for the group of statements for variable $B$ are given in Table 6. Statement $B_{4}$-has the highest mean score of 4.0220588 , and statement $B_{8}$ - the lowest mean score of 3.5955882. The average score of variable B is 3.8566176 .

Table 6. Descriptive statistics for all variables related to B.

\begin{tabular}{ccccc}
\hline B & $\mathbf{B}_{\mathbf{1}}$ & $\mathbf{B}_{\mathbf{2}}$ & $\mathbf{B}_{\mathbf{3}}$ & $\mathbf{B}_{\mathbf{4}}$ \\
\hline Mean & 3.9338235 & 3.6985294 & 3.9117647 & 4.0220588 \\
Std Dev & 1.0968116 & 1.2130149 & 0.8816700 & 0.9772745 \\
Std Err Mean & 0.0940508 & 0.1040152 & 0.0756026 & 0.0838006 \\
Upper 95\% Mean & 4.1198271 & 3.9042394 & 4.0612833 & 4.1877906 \\
Lower 95\% Mean & 3.7478200 & 3.4928194 & 3.7622461 & 3.856327 \\
$\mathrm{~N}$ & 136 & 136 & 136 & 136 \\
\hline
\end{tabular}


Table 6. Cont.

\begin{tabular}{|c|c|c|c|c|}
\hline B & $\mathbf{B}_{5}$ & $\mathbf{B}_{6}$ & $\mathbf{B}_{7}$ & $\mathbf{B}_{8}$ \\
\hline Mean & 4.0000000 & 3.9044118 & 3.7867647 & 3.5955882 \\
\hline Std Dev & 0.9737290 & 0.9728056 & 0.9615427 & 1.0064877 \\
\hline Std Err Mean & 0.0834966 & 0.0834174 & 0.0824516 & 0.0863056 \\
\hline Upper $95 \%$ Mean & 4.1651305 & 4.0693857 & 3.9498286 & 3.7662742 \\
\hline Lower $95 \%$ Mean & 3.8348695 & 3.7394378 & 3.6237008 & 3.4249023 \\
\hline $\mathrm{N}$ & 136 & 136 & 136 & 136 \\
\hline B & \multicolumn{4}{|c|}{ All variables B } \\
\hline Mean & \multicolumn{4}{|c|}{3.8566176} \\
\hline Std Dev & \multicolumn{4}{|c|}{0.6407333} \\
\hline Std Err Mean & \multicolumn{4}{|c|}{0.0549424} \\
\hline Upper $95 \%$ Mean & \multicolumn{4}{|c|}{3.9652769} \\
\hline Lower 95\% Mean & \multicolumn{4}{|c|}{3.7479584} \\
\hline $\mathrm{N}$ & \multicolumn{4}{|c|}{136} \\
\hline
\end{tabular}

The values of descriptive statistics for the group of statements for variable $\mathrm{C}$ are given in Table 7. Statement $C_{1}$-has the highest mean score of 3.9191176, and statement $C_{3}$ - the lowest mean score of 3.7720588 . The mean score of variable $\mathrm{C}$ is 3.8357843 .

Table 7. Descriptive statistics for all variables related to $C$.

\begin{tabular}{ccccc}
\hline $\mathbf{C}$ & $\mathbf{C}_{\mathbf{1}}$ & $\mathbf{C}_{\mathbf{2}}$ & $\mathbf{C}_{\mathbf{3}}$ & All Variable C \\
\hline Mean & 3.9191176 & 3.8161765 & 3.7720588 & 3.8357843 \\
Std Dev & 0.9510629 & 1.0968116 & 1.1480541 & 1.0126739 \\
Std Err Mean & 0.0815530 & 0.0940508 & 0.0984448 & 0.0868361 \\
Upper 95\% Mean & 4.0804043 & 4.0021800 & 3.9667524 & 4.0075193 \\
Lower 95\% Mean & 3.7578310 & 3.6301729 & 3.5773652 & 3.6640493 \\
$\mathrm{~N}$ & 136 & 136 & 136 & 136 \\
\hline
\end{tabular}

The values of descriptive statistics for the group of statements for the variable $\mathrm{D}$ are given in Table 8 . Statement $\mathrm{D}_{1}$ has the highest mean score of 4.0000000 , and statement $\mathrm{D}_{2}$ has the lowest mean score of 3.7794118. The mean score of variable D is 3.8921569 .

Table 8. Descriptive statistics for all variables related to D.

\begin{tabular}{ccccc}
\hline $\mathbf{D}$ & $\mathbf{D}_{\mathbf{1}}$ & $\mathbf{D}_{\mathbf{2}}$ & $\mathbf{D}_{\mathbf{3}}$ & All Variable D \\
\hline Mean & 4.0000000 & 3.7794118 & 3.8970588 & 3.8921569 \\
Std Dev & 0.9888265 & 1.0797200 & 1.1371140 & 0.7199478 \\
Std Err Mean & 0.0847912 & 0.0925852 & 0.0975067 & 0.0617350 \\
Upper 95\% Mean & 4.1676908 & 3.9625168 & 4.0898971 & 4.0142497 \\
Lower 95\% Mean & 3.8323092 & 3.5963067 & 3.7042205 & 3.7700640 \\
$\mathrm{~N}$ & 136 & 136 & 136 & 136 \\
\hline
\end{tabular}

\subsection{Results of Multiple Correlation and Regression Analysis (SEM)}

The basic standard evaluation of the system model was performed (Appendix A Figure A1, figure on the left). The coefficient of determination is 0.868535 , which means that the dependent variable D-Sustainability of maintenance of technical systems — can be explained by other independent variables with $86.85 \%$ of the variability. The correlation of the variables is strong. The values of the correlation coefficients are also given, where we can see that the largest correlation between the independent variables A and B is 0.7243 and it is of medium strength. The smallest correlation is between the independent variables $\mathrm{A}$ and $\mathrm{C}$. It is to -0.0117 , and it is negative and insignificant. The independent variable A, which is 0.5289 , has the largest impact on the dependent variable D-Sustainability of maintenance of technical systems and then then the variable B which is 0.3818 . The least impact has the independent variable $C$ which is 0.2622 .

The assessment of statistical significance is given in Table 9, and it is $[\mathrm{F}(3132)=$ $290.6897, p<0.0001]$. 
Table 9. ANOVA.

\begin{tabular}{ccccc}
\hline Source & DF & Sum of Squares & Mean Square & F Ratio \\
\hline Model & 3 & 60.774739 & 20.2582 & 290.6897 \\
Error & 132 & 9.199117 & 0.0697 & Prob $>$ F \\
C. Total & 135 & 69.973856 & & $<0.0001$ \\
\hline
\end{tabular}

Based on the data from (Table 9), the main null hypothesis $\mathrm{H}_{0}$ can be confirmed: Levels A-Application of technical diagnostics, B-Management of maintenance resources, and C-Maintenance process planning, significantly affect the level D-Sustainability of maintenance of technical systems.

Non-standard contribution values for the set system model are given in (Appendix A Figure A1, figure on the right). The highest mean score is for the independent variable $\mathrm{A}$ and is 3.8695 , and the lowest for the independent variable $C$ is 3.8358 . The largest value for the variance is the size of the independent variable $C 1.0180$, and the smallest variance is for the dependent variable D-Sustainability of maintenance of technical systems-and it is 0.0676 . The largest value of covariance is between the independent variables A and B, and it is 0.4549 , and the smallest is between the independent variables $A$ and $C$, and it is -0.0116 . The size of the intercept is 0.0303 . The highest non-standardized value has the variable $B$, and it is 0.429054 , followed by the variable $A$ with the value of 0.3856187 . The lowest value has the variable $\mathrm{C} 0.1864136$.

Based on the data from (Appendix A Figure A1, figure on the right), a multiple regression equation (Formulas (12) and (13) to seven decimal places) can be formed:

$$
y=0.0302714+0.3856187 \cdot x_{1}+0.429054 \cdot x_{2}+0.1864136 \cdot x_{3}
$$

or

$$
\begin{gathered}
D(\text { Sustainability of maintenance of technical systems })= \\
=0.0302714+0.3856187 \cdot A(\text { Application of technical diagnostics })+ \\
+0.429054 \cdot B(\text { Management of maintenance resources })+ \\
+0.1864136 \cdot C(\text { Maintenance process planning })
\end{gathered}
$$

The Diagram of the multiple regression equation is given in (Appendix B Figure A2), based on which we can give a sample of the research and set the system model to predict the variable D-Sustainability of maintenance of technical systems.

\subsection{Results of F-DEMATEL Method}

A team of 10 experts in the field of maintenance of technical systems conducted the survey. They were provided by the authors of the paper. Experts compared the criteria A-Application of technical diagnostics, B-Management of maintenance resources, and C-Maintenance process planning.

This part of the research was done after the responses of 136 the respondents had been analyzed in the period from 11 November 2020 to 1 December 2020. The following is a calculation for the F-DEMATEL method. Linguistic values of the influence of the above mentioned 10 experts for the variables (criteria) A, B, and C are given in Table 10.

Table 10. Opinions of 10 experts on the variables set-linguistic values.

\begin{tabular}{cccc}
\hline & A & B & C \\
\hline A & NI & HI, MI, HI, VHI, VHI, & MI, HI, LI, HI, MI, HI, \\
B & HI, MI, VHI, LI \\
& CHI, HI, VHI, HI, & MI, VHI, VHI & MI, HI, LI, MI, HI, HI, \\
& LHI, MI, MI, MI \\
& LI, MI, HI, HI, VHI, HI, & MI, LI, VHI, HI, MI, MI, & LI, HI, HI, MI \\
\hline
\end{tabular}

Legend: NI-no influence; LI-low influence; MI-medium influence; HI-high influence; VHI-very high influence. 
The results of the influence of 10 experts for the variables $\mathrm{A}, \mathrm{B}$, and $\mathrm{C}$ are given in Table 11.

Table 11. Results of the influence of the opinion of 10 experts on the variables set.

\begin{tabular}{cccc}
\hline & A & B & C \\
\hline A & 0 & $3,2,3,4,4,2,3,3,4,4$ & $2,3,1,3,2,3,3,2,4,1$ \\
B & $3,4,3,4,3,4,2,4,3,3$ & 0 & $2,3,1,2,3,3,1,3,2,2$ \\
C & $1,2,3,3,4,3,1,3,3,2$ & $2,1,4,3,2,2,1,2,2,3$ & 0 \\
\hline
\end{tabular}

The average opinions of 10 experts for the variables A, B, and C are given in Table 12 . They are derived as the mean value of the response for the variable expressed by the crips number.

Table 12. Average opinions of 10 experts on the variables set.

\begin{tabular}{ccccc}
\hline & A & B & C & $\boldsymbol{\Sigma}$ \\
\hline $\mathbf{A}$ & 0.0000 & 0.8300 & 0.6050 & 1.4350 \\
$\mathbf{B}$ & 0.8700 & 0.0000 & 0.5500 & 1.4200 \\
$\mathbf{C}$ & 0.6450 & 0.5250 & 0.0000 & 1.1700 \\
\hline $\boldsymbol{\Sigma}$ & 1.5150 & 1.3550 & 1.1550 & 4.0250 \\
\hline
\end{tabular}

The values $(\mathrm{N})$ of the normalized initial matrix of influence of 10 experts for variables $\mathrm{A}, \mathrm{B}$, and $\mathrm{C}$ are given in Table 13.

Table 13. Normalized initial matrix of influence of 10 experts on set variables.

\begin{tabular}{cccc}
\hline & A & B & C \\
\hline A & 0.000000000 & 0.578397213 & 0.421602787 \\
B & 0.606271777 & 0.000000000 & 0.383275261 \\
C & 0.449477352 & 0.365853659 & 0.000000000 \\
\hline
\end{tabular}

The procedure for determining the matrix of total relations for the variables $A, B$, and $\mathrm{C}$ is given in (Appendix C, formulas (A1)-(A7)). The total relations for the variables A, B, and $\mathrm{C}$ are given in Table 14.

Table 14. Matrix of the total relations for the variables A, B, and C.

\begin{tabular}{ccccccccccccc}
\hline & $\mathbf{A}$ & $\mathbf{B}$ & $\mathbf{C}$ & $\mathbf{D}_{\mathbf{i}}$ & $\mathbf{R}_{\mathbf{j}}$ & $\mathbf{D}_{\mathbf{i}}+\mathbf{R}_{\mathbf{j}}$ & $\mathbf{( D i}+\mathbf{R} \mathbf{j})_{\text {rank }}$ & $\mathbf{D}_{\mathbf{i}}-\mathbf{R}_{\mathbf{j}}$ & $\left.\mathbf{( D}_{\mathbf{i}}-\mathbf{R}_{\mathbf{j}}\right)_{\text {rank }}$ & $\boldsymbol{\omega}_{\mathbf{i}}$ & $\mathbf{W}_{\mathbf{i}}$ & $\mathbf{W}_{\mathbf{i} \text { rank }}$ \\
\hline $\mathbf{A}$ & 5.80 & 5.79 & 5.09 & 16.68 & 17.26 & 33.94 & 1 & -0.58 & 1 & 33.95 & $35.59 \%$ & 1 \\
$\mathbf{B}$ & 6.16 & 5.41 & 5.05 & 16.62 & 16.15 & 32.77 & 2 & 0.47 & 2 & 32.77 & $34.36 \%$ & 2 \\
$\mathbf{C}$ & 5.31 & 4.95 & 4.13 & 14.39 & 14.27 & 28.67 & 3 & 0.12 & 3 & 28.67 & $30.05 \%$ & 3 \\
& & & & & Mean & 31.79 & Mean & 0.00 & $\boldsymbol{\Sigma}$ & 95.39 & $100.00 \%$ & \\
\hline
\end{tabular}

The threshold value is derived from the arithmetic mean from the matrix of total relations ( $\mathrm{T}$ ) and used via formula (11), and it is $\alpha=5.30$. A causal diagram of the performance and significance of the variables set (criteria) for $A, B$, and $C$ is given in (Figure 2) according to (Vafadarnikjoo et al. 2015).

Based on the obtained values that represent the importance and influence of the examined variables, i.e., criteria, and their normed rank values, we can see that the most important criterion for the number of experts set is the criterion A-Application of technical diagnostics 33.95 or $(35.59 \%$, (1)), then the criterion B-Management of maintenance resources 32.77 or $(34.36 \%,(2))$, and finally the criterion $\mathrm{C}-$ Maintenance process planning 28.67 or $(30.05 \%,(3))$. 


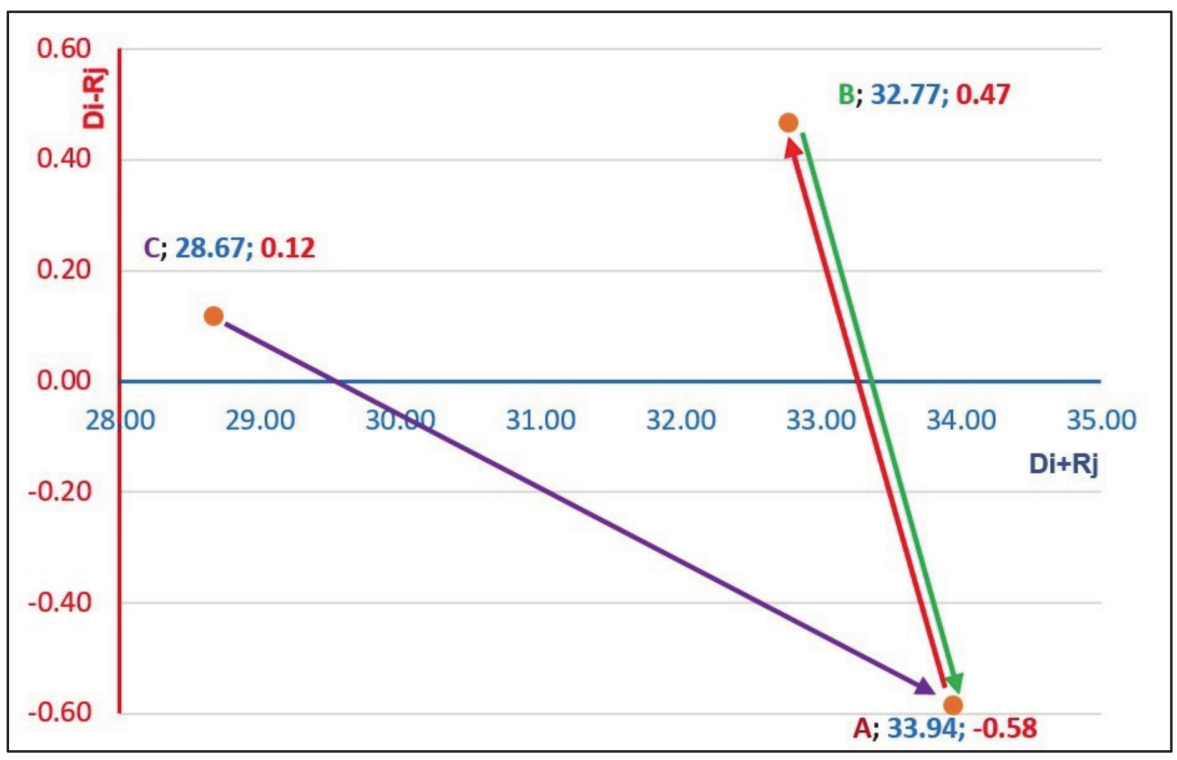

Figure 2. Causal diagram of the performance and significance of the variables set.

\section{Conclusions}

According to 136 respondents, the independent variable A-Application of technical diagnostics - has the greatest impact on the Sustainability of technical system maintenance, followed by the variable B-Management of maintenance resources. The independent variable $\mathrm{C}$-Maintenance process planning — has the smallest impact. The main null hypothesis, $\mathrm{H} 0$, has been confirmed, namely, that Levels A-Application of technical diagnostics, BManagement of maintenance resources, and $\mathrm{C}-$ Maintenance process planning and the dependent variable significantly affect the level D-Sustainability of technical system maintenance. The F-DEMATEL method has proven to be suitable for solving problems of ranking the impact of certain criteria in the function of achieving sustainability with group decision-making in a gentle environment. This method is excellent and important for decision makers in the areas of technical systems maintenance because it can be used to investigate any complex technical decision problem. The results obtained based on the opinion of 10 experts on the criteria set are shown in the Causal Diagram. The importance of the criterion rank is shown on the $\left(D_{i}+R_{j}\right)$ axis. It determines the success factor, which is ranked according to the following importance: the criterion A-Application of technical diagnostics $>\mathrm{B}$-Management of maintenance resources $>\mathrm{C}$-Maintenance process planning. The criterion A has the greatest impact on the sustainability of maintenance of technical systems. According to experts, the importance of the criteria coincides with the results obtained by a survey with 136 respondents.

This study showed that the criteria: A-Application of technical diagnostics, BManagement of maintenance resources, and $\mathrm{C}$-Maintenance process planning are ranked by importance based on the highest $\left(D_{i}+R_{j}\right)$ values of 33.94, 32.77, and 28.67. Criteria $\mathrm{B}$ Management of maintenance resources and $\mathrm{C}$-Maintenance process planning are in the group of causes based on their positive $\left(D_{i}-R_{j}\right)$ values of 0.47 and 0.12 . Criterion A-Application of technical diagnostics is in the group of effects, considering its negative $\left(D_{i}-R_{j}\right)$ value of -0.58 . From (Figure 2) we can see that criterion B-Management of maintenance resources-is the most critical because it directly affects criterion A-Application of technical diagnostics, followed by criterion $\mathrm{C}$ - Maintenance process planning, which also affects criterion A-Application of technical diagnostics. Criterion B-Management of maintenance resources-has the most effect on criterion A-Application of technical diagnostics and these criteria directly interact with each other.

Author Contributions: Conceptualization, G.O., O.M., and L.R.; methodology, O.M.; validation, G.O., O.M., and G.J.; formal analysis, O.M. and L.R.; investigation, G.O., O.M., and L.R.; resources, 
G.O, D.R., and J.P.; data curation, G.J., D.R., and J.P.; writing-original draft preparation, G.O., O.M., and L.R.; writing-review and editing, O.M., L.R., D.R., and J.P.; visualization, G.J.; supervision, G.J., D.R., and J.P. All authors have read and agreed to the published version of the manuscript.

Funding: This research received no external funding.

Acknowledgments: The authors would like to thank the Ministry of Education, Science and Technological Development of the Republic of Serbia for financial support.

Conflicts of Interest: The authors declare no conflict of interest.

Appendix A. Standard (Figure on the Left) and Non-Standard (Figure on the Right) Contribution Sizes of the System Model
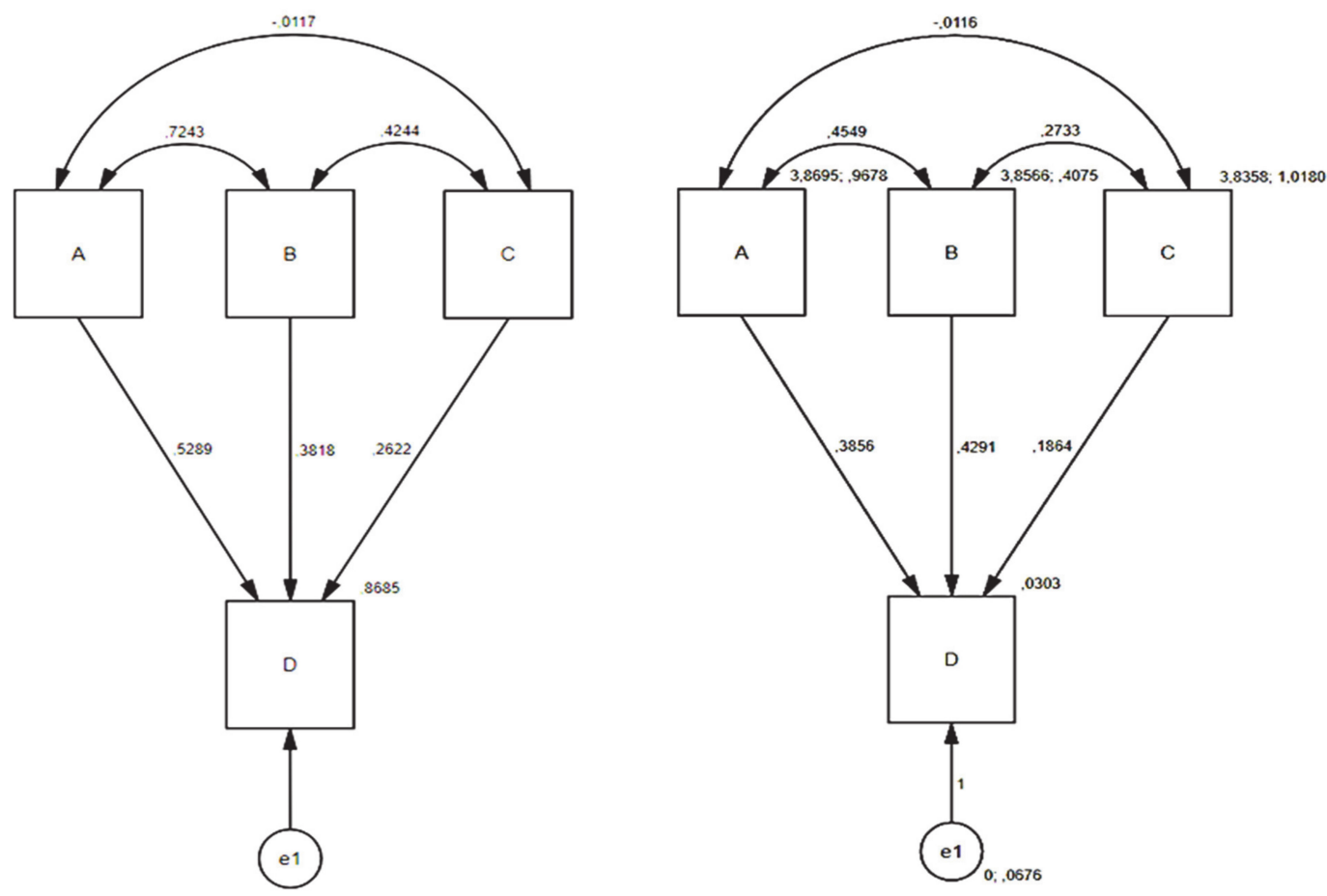

Figure A1. Standard (figure on the left) and non-standard (figure on the right) contribution sizes of the System Model.

Appendix B. Diagram of Multiple Regression Equation

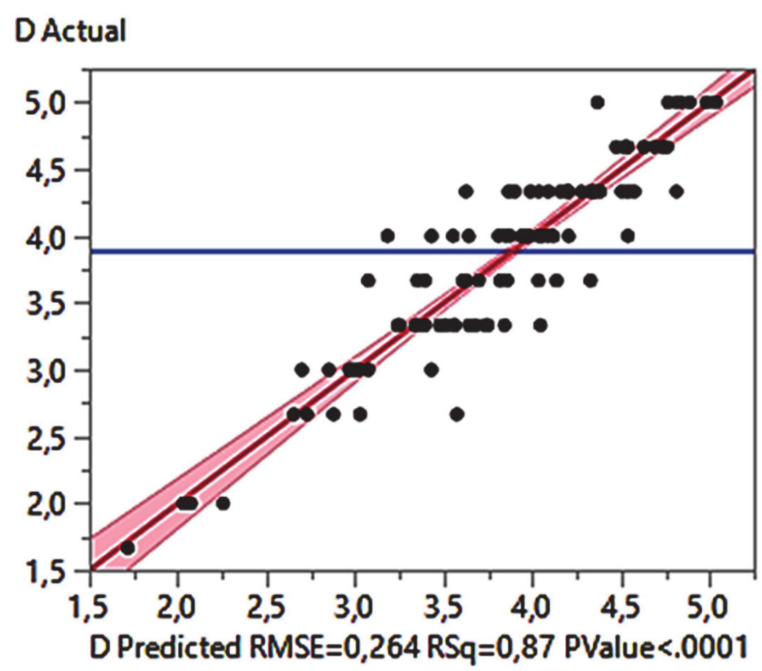

Figure A2. Diagram of multiple regression equation. 


\section{Appendix C. Procedure for Determining the Matrix of Total Relations for Variables A-Application of Technical Diagnostics, B-Management of Maintenance Resources, C-Maintenance Process Planning}

The procedure for determining the matrix of total relations for the variables $\mathrm{A}-$ Application of technical diagnostics, B-Management of maintenance resources, CMaintenance process planning is shown using the following (formulas (A1)-(A7)).

$$
T=N \times(I-N)^{-1}
$$

wherein:

$$
\begin{gathered}
\text { (I) unit matrix }\left(\begin{array}{lll}
1 & 0 & 0 \\
0 & 1 & 0 \\
0 & 0 & 1
\end{array}\right) \\
(N) \text { standardized matrix }\left(\begin{array}{ccc}
0 & 0.578397213 & 0.421602787 \\
0.606271777 & 0 & 0.383275261 \\
0.449477352 & 0.365853659 & 0
\end{array}\right)
\end{gathered}
$$

$$
(I-N)\left(\begin{array}{lll}
1 & 0 & 0 \\
0 & 1 & 0 \\
0 & 0 & 1
\end{array}\right)-\left(\begin{array}{ccc}
0 & 0.578397213 & 0.421602787 \\
0.606271777 & 0 & 0.383275261 \\
0.449477352 & 0.365853659 & 0
\end{array}\right)=\left(\begin{array}{ccc}
1 & -0.578 & -0.422 \\
-0.606 & 1 & -0.383 \\
-0.449 & -0.366 & 1
\end{array}\right)
$$

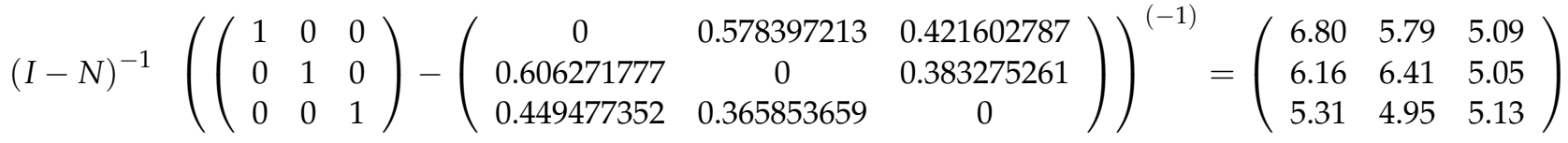

$$
T=N \times(I-N)^{-1} \text { matrix of total relations }
$$

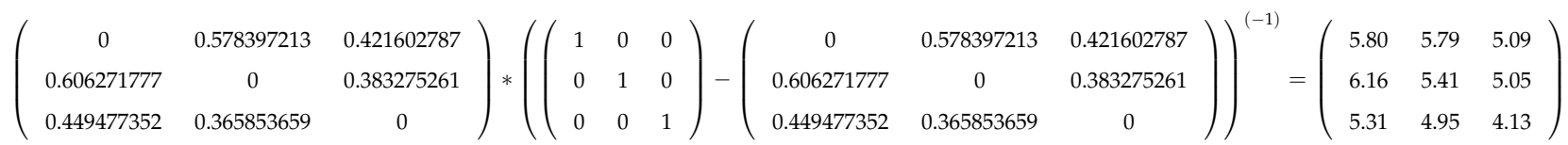

\section{References}

1. Bulatović, M. Održavanje u funkciji održivog razvoja. In Proceedings of the 2th Conference Maintenance 2012, Zenica, Bosnia and Herzegovina, 10-13 June 2012. (In Montenegrin).

2. Afrinaldi, F.; Tasman, A.M.; Zhang, H.C.; Hasan, A. Minimizing economic and environmental impacts through an optimal preventive replacement schedule: Model and application. J. Clean. Prod. 2017, 143, 882-893. [CrossRef]

3. Sari, E.; Shaharoun, A.B.M.; Ma'aram, A.B. Preliminary Framework of Sustainable Maintenance Performance Measurement Systems for Automotive Companies. In Advanced Materials Research; Trans Tech Publications: Stafa-Zurich, Switzerland, 2014; Volume 845, pp. 590-595.

4. Sari, E.; Shaharoun, A.M.; Ma'aram, A.; Yazid, A.M. Sustainable maintenance performance measures: A pilot survey in Malaysian automotive companies. Procedia CIRP 2015, 26, 443-448. [CrossRef]

5. Sénéchal, O. Research directions for integrating the triple bottom line in maintenance dashboards. J. Clean. Prod. 2017, 142, 331-342. [CrossRef]

6. Amrina, E.; Aridharma, D. Sustainable maintenance performance evaluation model for cement industry. In Proceedings of the International Conference on Industrial Engineering and Engineering Management (IEEM), Bali, Indonesia, 4-7 December 2016; pp. 350-354. [CrossRef]

7. Heravi, G.; Fathi, M.; Faeghi, S. Evaluation of sustainability indicators of industrial buildings focused on petrochemical projects. J. Clean. Prod. 2015, 109, 92-107. [CrossRef]

8. Pires, S.P.; Sénéchal, O.; Loures, E.F.R.; Jimenez, J.F. An approach to the prioritization of sustainable maintenance drivers in the TBL framework. IFAC-PapersOnLine 2016, 49, 150-155. [CrossRef]

9. Domingo, R.; Aguado, S. Overall environmental equipment effectiveness as a metric of a lean and green manufacturing system. Sustainability 2015, 7, 9031-9047. [CrossRef]

10. Franciosi, C.; Iung, B.; Miranda, S.; Riemm, S. Maintenance for Sustainability in the Industry 4.0 context: A Scoping Literature Review. IFAC-PapersOnLine 2018, 51, 903-908. [CrossRef] 
11. Sodangi, M.; Khamdi, M.F.; Idrus, A.; Hammad, D.B.; Umar, A.A. Best Practice Criteria for Sustainable Maintenance Management of Heritage Buildings in Malaysia. Procedia Eng. 2014, 77, 11-19. [CrossRef]

12. Jasiulewicz-Kaczmarek, M. The role and contribution of maintenance in sustainable manufacturing. In Proceedings of the FAC Conference on Manufacturing Modelling, Management, and Control, Saint Petersburg State University and Saint Petersburg National Research University of Information Technologies, Mechanics, and Optics, Saint Petersburg, Russia, 19-21 June 2013.

13. Kanisuru, A.M. Sustainable Maintenance Practices and Skills for Competitive Production System. Chapter 3. Available online: https:/ / www.intechopen.com/books/skills-development-for-sustainable-manufacturing/sustainable-maintenancepractices-and-skills-for-competitive-production-system (accessed on 27 December 2020).

14. Kilić Pamuković, J.; Rogulj, R.; Dumanić, D.; Jajac, N. A Sustainable Approach for the Maintenance of Asphalt Pavement Construction. Sustainability 2021, 13, 109. [CrossRef]

15. Çınar, Z.M.; Nuhu, A.A.; Zeeshan, Q.; Korhan, O.; Asmael, M.; Safaei, B. Machine Learning in Predictive Maintenance towards Sustainable Smart Manufacturing in Industry 4.0. Sustainability 2020, 12, 8211. [CrossRef]

16. Adamović, Ž. Tehnologija Održavanja; University of Novi Sad, Technical Faculty “Mihajlo Pupin”: Zrenjanin, Serbia, 2004. (In Serbian)

17. Radovanović, L. Metodologije Održavanja sa Aspekta Njihove Primene u Industriji. Ph.D. Thesis, University of Novi Sad, Technical Faculty “Mihajlo Pupin”, Zrenjanin, Serbia, 2012. (In Serbian).

18. Todorović, J. Inženjerstvo Održavanja Tehničkih Sistema; Jugoslovensko Društvo za Motore i Vozila: Beograd, Serbia, 1993. (In Serbian)

19. Todorović, J. Osnovi Teorije Održavanja; Mašinski Fakultet Beograd: Beograd, Serbia, 1984. (In Serbian)

20. Todorović, J. Upravljanje održavanjem na bazi rizika. J. Appl. Eng. Sci. 2003, 1, 23-32. (In Serbian)

21. Stanivuković, D.; Kecojević, S. Održavanje-Prilaz Projektovanju i Upravljanju; IIS-Istraživački i Tehnološki Centar; FTN-Institut za Industrijske Sisteme: Novi Sad, Serbia, 1995. (In Serbian)

22. Stanivuković, D.; Zelenović, D.; Kecojević, S. Održavanje-IIS Prilaz; IIS-Istraživački i Tehnološki Centar; FTN-Institut za Industrijske Sisteme: Novi Sad, Serbia, 1997. (In Serbian)

23. Vasić, B. Upravljanje Održavanjem; OMO: Beograd, Serbia, 1997. (In Serbian)

24. Jeremić, B.; Todorović, T.; Mačudžić, I. Inženjering Održavanja-Skripta; Mašinski Fakultet Kragujevac: Kragujevac, Serbia, 2008. (In Serbian)

25. Wireman, T. World Class Maintenance Management; Industrial Pres, Inc.: New York, NY, USA, 1990.

26. Wireman, T. Total Productive Maintenance: An American Approach; Industrial Pres, Inc.: New York, NY, USA, 1991.

27. Wireman, T. Developing Performance Indicators for Managing Maintenance; Industrial Pres, Inc.: New York, NY, USA, 2005.

28. Liyanage, J.P.; Kumar, U. Towards a value-based view on operations and maintenance performance management. J. Qual. Maint. Eng. 2003, 9, 333-350. [CrossRef]

29. Milosavljević, P. Modeliranje Procesa Održavanja Tehničkih Sistema na Konceptu Totalnog Produktivnog Održavanja. Ph.D. Thesis, University of Niš, Mechanical Faculty, Niš, Serbia, 2005. (In Serbian).

30. Šćepanović, S. Efikasnost Modela Održavanja Termoelektrana. Ph.D. Thesis, University of Novi Sad, Technical Faculty “Mihajlo Pupin", Zrenjanin, Serbia, 2006. (In Serbian).

31. Nikolić, D. Optimizacija Postupaka Tehničke Dijagnostike Hidroelektrana. Ph.D. Thesis, University of Novi Sad, Technical Faculty “Mihajlo Pupin”, Zrenjanin, Serbia, 2007. (In Serbian).

32. Kutin, M. Optimizacija Primene Dijagnostičkih Tehnika i Njihov Uticaj na Pouzdanost Tehničkih Sistema. Ph.D. Thesis, University of Novi Sad, Technical Faculty “Mihajlo Pupin”, Zrenjanin, Serbia, 2010. (In Serbian).

33. Anderson, J.; Gerbing, D. Structural equation modeling in practice: A review and recommended two-step approach. Psychol. Bull. 1988, 103, 411-423. [CrossRef]

34. DiLalla, L. Structural equation modeling: Uses and issues. In Handbook of Applied Multivariate Statistics and Mathematical Modeling; Academic Press: Cambridge, MA, USA, 2000; pp. 439-464.

35. Fajgelj, S.; Kuzmanović, B.; Đukanović, B. Priručnik za Socijalna Istraživanja; CID: Podgorica, Montenegro, 2014. (In Montenegrin)

36. Fassinger, R. Use of structural equation modeling in counseling psychology research. J. Couns. Psychol. 1987, 34, 425. [CrossRef]

37. Long, B.; Kahn, S.; Schutz, R. Causal model of stress and coping: Women in management. J. Couns. Psychol. 1992, 39, 227-239. [CrossRef]

38. Smederevac, S.; Mitrović, D.; Čolović, P.; Nikolašević, Ž. Validation of the measure of revised reinforcement sensitivity theory constructs. J. Individ. Differ. 2014, 35, 12-21. [CrossRef]

39. Iacobucci, D. Structural equations modeling: Fit indices, sample size, and advanced topics. J. Consum. Psychol. 2010, 20, 90-98. [CrossRef]

40. Hu, L.; Bentler, M. Cutoff criteria for fit indexes in covariance structure analysis: Conventional criteria versus new alternatives. Struct. Equ. Model. A Multidiscip. J. 1999, 6, 1-55. [CrossRef]

41. Govindan, K.; Khodaverdi, R.; Vafadarnikjoo, A. A grey DEMATEL approach to develop third-party logistics provider selection criteria. Ind. Manag. Data Syst. 2016, 116, 690-722. [CrossRef]

42. Vafadarnikjoo, A.; Mobin, M.; Salmon, C.; Javadian, N. An integrated gray-fuzzy cause-effect approach to determine the most significant categories of project risks. In Proceedings of the Industrial and Systems Engineering Research Conference (ISERC), Nashville, TN, USA, 30 May-2 June 2015.

43. Zadeh, L.A. Fuzzy sets. Inf. Control 1965, 8, 338-353. [CrossRef] 
44. Lin, R.J. Using fuzzy DEMATEL to evaluate the green supply chain management practices. J. Clean. Prod. 2013, 40, 32-39. [CrossRef]

45. Baykasoglu, A.; Kaplanoğlu, V.; Durmusoglu, Z.; Şahin, C. Integrating fuzzy DEMATEL and fuzzy hierarchical TOPSIS methods for truck selection. Expert Syst. Appl. 2013, 40, 899-907. [CrossRef]

46. Dalalah, D.; Hayajneh, M.; Batieha, F. A Fuzzy Multi-Criteria Decision-Making Model for Supplier Selection. Expert Syst. Appl. 2011, 38, 8384-8391. [CrossRef] 